\title{
STORAGE CONDITIONS OF AVULSED TEETH AFFECT THE PHENOTYPE OF CULTURED HUMAN PERIODONTAL LIGAMENT CELLS
}

by

Deborah G. Lin, B.Sc., D.D.S., Dip. Paed. Dent.

A Thesis submitted in conformity with the requirements for the Degree of Master of Science Graduate Department of Dentistry University of Toronto

๑) Copyright by Deborah G. Lin 1999 
National Library of Canada

Acquisitions and Bibliographic Services

395 Wellington Street Ottawa ON K1A ON4 Canada
Bibliothèque nationale du Canada

Acquisitions et services bibliographiques

395 , rue Wellington Ottawa ON K1A ON4 Canada
The author has granted a nonexclusive licence allowing the National Library of Canada to reproduce, loan, distribute or sell copies of this thesis in microform, paper or electronic formats.
The author retains ownership of the copyright in this thesis. Neither the thesis nor substantial extracts from it may be printed or otherwise reproduced without the author's permission.
L'auteur a accordé une licence non exclusive permettant à la Bibliothèque nationale du Canada de reproduire, prêter, distribuer ou vendre des copies de cette thèse sous la forme de microfiche/film, de reproduction sur papier ou sur format électronique.

L'auteur conserve la propriété du droit d'auteur qui protège cette thèse. $\mathrm{Ni}$ la thèse ni des extraits substantiels de celle-ci ne doivent être imprimés ou autrement reproduits sans son autorisation. 


\title{
STORAGE CONDITIONS OF AVULSED TEETH AFFECT THE PHENOTYPE OF CULTURED HUMAN PERIODONTAL LIGAMENT CELLS
}

\author{
Deborah G. Lin, B.Sc., D.D.S., Dip. Paed. Dent. \\ A Thesis submitted in conformity with the requirements \\ for the Degree of Master of Science Graduate Department of Dentistry \\ University of Toronto
}

(C) Copyright by Deborah G. Lin 1999

\begin{abstract}
Immunohistochemical staining of markers expressed by osteogenic cells and fibroblasts were examined. Extracted human premolar teeth stored in air ("dry") or $\alpha-M E M$ ("wet") for 30 or 120 minutes as conditions for extra-alveolar tooth storage following avulsion. For type XII collagen, wet samples exhibited perinuclear staining while 30 minutes dry samples showed isolated foci. Staining for 120 minutes dry samples was weak and non-specific. $\alpha$-smooth muscle actin was prominent in stress fibres in dry samples. Staining for osteopontin was perinuclear but more intense in dry samples. The focal adhesion pattern of osteop ontin in 120 minutes dry samples resembled that of migrating osteogenic cells. Pattern of staining did not vary for type III collagen or alkaline phosphatase, but was more intense in dry samples. Prclonged extra-alveolar dry storage favours increased in vitro growth of œlls expressing osteogenic cell markers while storage in wet favours growth of cells with the PL fibroblast phenotype.
\end{abstract}




\section{Acknowledgements}

I would like to thank Cheung Lo and Harry Moe for their help with cell culture. Pam Arora's support in immunostaining was invaluable. I am indebted to Dr. David Kenny and Christopher McCulloch for all their support and helpful comments. This research was supported, in part, by the Hospital for Sick Children Foundation's New Initiatives Grant.

A special thanks to my parents, brother, and sister. Without their love and support, I would not be where I am today.

This thesis, in part, has been submitted to the Journal of Periodontal Research for publication. 


\section{Table of Contents}

Abstract Ai

Acknowledgements $\quad$ iii

Table of Contents iv

List of Tables $\quad v$

List of Figures vi vi vis

A Review of the Biological Basis of Clinical Management

of Avulsed Permanent Teeth 1

PL Cell Physiology 2

Principles of PL Wound Healing 4

Cellular Response to Acute Trauma $\quad 7$

Pre-Replantation Duration and Storage $\quad 7$

Pre-Replantation Contamination 9

$\begin{array}{ll}\text { Post-Replantation Sequelae } & 10\end{array}$

Long Term Effects of PL Wound Healing 10

Guidelines for Management 11

Statement of the Problem 11

$\begin{array}{ll}\text { Hypothesis } & 12\end{array}$

$\begin{array}{ll}\text { Objectives } & 12\end{array}$

$\begin{array}{ll}\text { Rationale } & 12\end{array}$

Materials and Methods $\quad 15$

$\begin{array}{ll}\text { Cell Culture } & 15\end{array}$

$\begin{array}{lr}\text { Immunofluorescence } & 15\end{array}$

Results 18

$\begin{array}{ll}\text { Validation of Methods } & 18\end{array}$

Type III Collagen $\quad 22$

Type XII Collagen $\quad 25$

$\alpha$-Smooth Muscle Actin $\quad 28$

Osteopontin $\quad 31$

Alkaline Phosphatase $\quad 34$

$\begin{array}{ll}\text { Discussion } & 37\end{array}$

$\begin{array}{ll}\text { Conclusions } & 40\end{array}$

Bibliography 41 


\section{List of Tables}

Table 1 Estimates of fluorescence intensity for intracellular periodontal cell markers 


\section{List of Figures}

Figure 1 Validation of Methods - Immunohistochemical Staining

Patterns for Negative and Positive Controls

Figure 2 Staining of Type III Collagen in Human PL Cells

Figure 3 Staining of Type XII Collagen in Human PL Cells

Figure 4 Staining of $\alpha$-Smooth Muscle Actin in Human PL Cells

Figure 5 Staining of Osteopontin in Human PL Cells

Figure 6 Staining of Alkaline Phosphatase in Human PL Cells 


\section{A REVIEW OF THE BIOLOGICAL BASIS OF CLINICAL MANAGEMENT OF AVULSED PERMANENT TEETH}

Dental avulsions occur when teeth are displaced from alveolar bone as a result of trauma (e.g. a blow). Avulsion injuries are most common in children between the ages of 7 and 10 years as the roots are usually incompletely formed and the supporting bone is easily deformed (Andreasen 1981b). Replantation is the most common treatment for avulsed permanent incisors and survival has been shown to vary with extra-alveolar time and root maturity (Andreasen et al. 1995d; Barrett and Kenny 1997).

Periodontal healing involves recolonization of the periodontal ligament (PL) space by PL cells and often ingrowth of bone with subsequent ankylosis (Melcher 1970). Form and function of the PL of replanted teeth is affected by cellular and PL necrosis and by mechanical damage to cementum and alveolar bone. Fibroblasts, the predominant cell type in human PL, are essential for healing and the relative abundance of discrete subpopulations affects the outcomes of regeneration and repair (Lekic and McCulloch 1996).

Experimental model systems are used to investigate the principles of PL healing and cellular viability. Both in vitro and in vivo model systems provide simplified approaches to treatment and storage conditions that may be encountered clinically. In vitro models utilize relatively homogeneous cell populations that can be analyzed independently of complicating in vivo factors. However, experimental designs should optimally mimic injury conditions in order for such model systems to be relevant to clinical practice. A number of model systems have utilized rodent (Lin et al. 1994), primate (Andreasen and Kristerson 1981) or human (Lekic et al. 1996b; Hiltz and Trope 1991) PL fibroblasts or other sources for in vitro observations of cell function. Species differences and variations of cell lineages can affect the validity of fibroblast model systems and introduce variables that further affect the scientific value of these systems, particularly when applied to human dental trauma investigations. For example, rodent models may not be comparable to those of humans and fibroblast populations from lip are not the same as those from PL. Caution is required when extending the results to clinical practice due to the diversity of experimental model systems. 
This review will provide an update on the cellular aspects of post-replantation healing of the PL as it pertains to avulsion injuries. Management aspects will include the linked variables of extra-alveolar time and storage conditions.

\section{PL Cell Physiology}

The PL and its associated cell populations are important for the maintenance of alveolar bone, cementum and tooth position (Lekic et al. 1996a). Cementum and alveolar bone are neighbouring mineralized connective tissues that are separated by the soft tissuecontaining periodontal space (Lekic and McCulloch 1996).

Melcher's (1970) observations of wound healing support the theory that connective tissues or cells of the PL possess the capacity to inhibit osteogenesis within the periodontal space and prevent root resorption. He also demonstrated that alveolar bone adjacent to the PL can be remodeled in orthodontic tooth movement, yet osteogenesis is inhibited from continuing through the PL to the root surface to produce ankylosis. These studies illustrate the necessity to maintain a functional PL over the entire root surface of traumatized teeth to prevent ankylosis.

Fibroblasts, epithelial cell rests of Malassez, macrophages, undifferentiated mesenchymal cells, neural elements and endothelial cells are all located in the PL. Cementoblasts are present on the root surface (Lekic and McCulloch 1996). Ten Cate and Deporter (1974) demonstrated that fibroblasts, the dominant cell type in the PL, are capable of synthesis and phagocytosis of both collagen and the extracellular matrix components of connective tissue. Fibroblasts produce cytokines that regulate tissue destruction and stimulate osteoclastic bone resorption. Experiments have demonstrated osteogenic precursor cells with the potential to become osteoblasts and/or osteoclasts distributed throughout the PL of rat molars (Roberts and Chase 1981).

Although their locations have been established, the exact origin of fibroblasts, cementoblasts and osteoblasts in mature PL remains unknown. It is unclear if these cells originate from single, multipotential stem cells or from a number of different stem cells (Lekic and McCulloch 1996). Cellular kinetic studies of root development in mice suggest that the developing root may be responsible for formation of the fibroblast stem 
cells during eruption (Perera and Tonge 1981). PL progenitor or stem cells are found in locations adjacent to blood vessels and exhibit some of the cytological features of stem cells such as small size, slow cycle time, and responsiveness to stimulating factors (McCulloch and Melcher 1983a). The mitoses of paravascular cells may produce primitive fibroblast progenitor cells (Gould et al. 1980). The daughter cells of these fibroblast progenitors are prime candidates for the repopulation of wounded PL. McCulloch and Melcher (1983b) demonstrated that the majority of proliferating paravascular cells are located in the central portion of the PL. In hamsters, it has been observed that gingival fibroblasts have two progenitor cell populations. One population has limited proliferative potential, but the other has extensive proliferative and selfrenewal capacities (McCulloch and Knowles 1991). It is unknown if comparable populations exist for human PL fibroblasts. Since developmental patterns that establish the initial locations of progenitor cells are preserved in the mature adult PL (Lekic and McCulloch 1996), the PL adjacent to the root contains cementoblast precursors, while the alveolar bone contains osteoblast precursors.

The PL of a functional tooth contains cell populations that have small but measurable rates of turnover that are essential for tissue homeostasis (McCulloch and Melcher 1983a). Homeostatic balance in renewal systems occurs when the new cells generated by proliferation are equal to the number of cells eliminated by migration and cell death (Gould et al. 1980; Lekic and McCulloch 1996).

Tissue markers, typically proteins that have been used to identify specific cell types, have been utilized to provide indirect evidence of the presence of discrete cell populations that are involved during PL healing. For example, it is thought that epidermal growth factor (EGF) plays a role in fibroblast differentiation and in vivo studies indicated the presence of EGF binding sites during PL fibroblast differentiation (Cho et al. 1991). Another marker for PL fibroblast differentiation is type XII collagen, an extracellular matrix glycoprotein. Oh et al. (1993) demonstrated type XII collagen production by PL fibroblasts occurred only when the PL was mature and functional. Karimbux and Nishimura (1995) reported that type XII collagen expression may be closely associated with the regeneration of a functional PL in rats. An extracellular matrix macromolecule 
that is expressed by differentiating osteogenic cells is osteopontin. Alkaline phosphatase is also expressed by mineralized tissue-forming cells. Both osteopontin and alkaline phosphatase are not specific for osteoblast precursor cells, but they have been shown to be expressed by mineralized tissue-forming cells in cultures derived from bone and in bone marrow stromal cells when differentiation was induced with dexamethasone, a corticosteriod (Groeneveld et al. 1993). Groeneveld et al. (1993) showed that alkaline phosphatase is expressed by rat PL cells and variations of its expression within the PL may be related to variations in phosphate metabolism and cementum deposition. If the PL contains substantial numbers of osteogenic cells, one would expect to identify the expression of osteopontin and alkaline phosphatase among bone-related PL cells (Lekic and McCulloch 1996), however, this has not been demonstrated to date. $\alpha$-smooth muscle actin is expressed in association with cell contractility. High levels of $\alpha$-smooth muscle actin in the PL fibroblast population suggests the presence of highly contractile cells of a specialized cell type (Arora and McCulloch 1994). It is expected that future studies will continue to utilize PL cell markers to facilitate the understanding of cellular dynamics during normal development as well as wound healing.

\section{Principles of PL Wound Healing}

The principal source of fibroblasts involved in PL wound healing appears to be from unwounded portions of periodontium. This indicates that early patterns of PL progenitor cell differentiation are preserved in the adult PL (McCulloch and Melcher 1983b; Lekic and McCulloch 1996). This model can be applied to lateral luxation, extrusion and some intrusion injuries, where there may be localized areas of unwounded periodontium. However, in avulsion injuries, the entire PL is injured and affected by extraoral storage conditions. Consequently, following replantation, fibroblasts of the PL that adhered to the root as well as injured cells within the alveolar PL may be replaced by osteoclastic and osteoblastic precursor cells derived from alveolar-based progenitor cells. This will lead to healing with root surface remodeling, ingress of bone and subsequent ankylosis. 
After PL trauma, two healing processes can occur: regeneration, healing where both form and function of the periodontium are fully restored, or repair, healing by tissue that does not fully restore the periodontium. Viable PL cells on the root of the traumatized tooth and in the alveolar socket that remain capable of expressing their full range of characteristics determine the balance between regeneration and repair. This balance directly affects the clinical outcomes of replantation.

Cells of the PL have a variety of roles in wound healing and depending upon the phenotype of the cell present, osteogenesis, osteoclasis, fibrogenesis, fibrociasis, cementogenesis, or cementoclasis may occur (Melcher 1976). Line et al. (1974) demonstrated that following thermal injury to the PL of squirrel monkey premolars, the majority of repopulating cells were derived from alveolar bone marrow. The observed outcome of ankylosis supports the hypotheses that cells from the alveolar bone repopulate PL that has been injured by either thermal or mechanical means. If alveolar bone and/or marrow cells repopulate the injured PL, they appear to retain their capacity for osteoclasis and osteogenesis but are incapable of differentiating into cells that are capable of regenerating normal PL tissue (Line et al. 1974).

The range of phenotypes of cells that repopulate the PL dictate tissue form and function at the healing site (Melcher 1976). If the proliferation of early progenitor cells could be regulated, the outcome of healing could be determined as repopulating cells arise from proliferating precursors (Evans and Potten 1991). In the PL of rats, Lekic et al. (1996b) showed that non-proliferative cells are present in a wound site. This finding indicates that the normal PL fibroblast population may contain some cells that are unable to proliferate and that repopulation of the PL may not occur from PL fibroblasts (Lekic and McCulloch 1996).

The location of cells within the PL may affect their role in migration as well. Osteogenic precursor cells from the alveolus may have a shorter distance to migrate to necrotic $\mathrm{PL}$ and areas of dentin denuded of cementum than surviving PL cells that adhere to other portions of the root (Melcher et al. 1987; Melcher 1976). Following replantation, the normally uniform PL thickness will vary due to damage to the root and socket architecture, the new position of the root and pressure points produced by splinting and 
function. This may also contribute to preferential colonization of the root surface by cells from the alveolus (Melcher 1976).

Patches of PL are torn from the root during trauma, post-trauma management and replantation. Root resorption then occurs at variable rates and is identified radiographically as inflammatory or replacement resorption. Inflammatory and replacement resorption occur as a direct result of an inflammatory response within the PL. At the cellular level, lymphocytes, plasma cells and polymorphonuclear leukocytes are seen in granulation tissue along with proliferating capillaries (Andreasen and HjørtingHansen 1966b). Along the root surface, resorption is observed with Howship's lacunae that contain osteoclasts. Osteoclasts cannot discern dentin and cementum from alveolar bone and resorb dentin and cementum as well as the socket wall. Replacement resorption differs from inflammatory resorption as cells from the adjacent bone marrow repopulate the PL. These cells have osteogenic potential and new bone is formed and obliterates the periodontal space to produce a direct contact between alveolar bone and root (Andreasen and Hjørting-Hansen 1966b).

Hammarström et al. (1989) investigated the histology of replacement resorption and ankylosis in monkey teeth. An unhealed separation line in the middle portion of the PL was seen in some areas up to one week following replantation. Osteoclasts could be observed to resorb the socket wall four days after replantation, and after one week, root resorption and ankylosis were observed. Ankylosis began with the apposition of bone-like tissue on the surface of cementum and with mineralized areas in the middle portion of the PL. Eight weeks post-replantation, most of the PL was replaced by bone lined with osteoblasts that faced the marrow spaces of the alveolar process. In previously resorbed areas, newly formed bone replaced cementum and dentin. Once ankylosis was established, cementoblasts and the PL were lost and the root surface became covered with osteoblasts and osteoclasts in continuity with endosteal cells that lined the marrow spaces of the alveolar bone (Hammarström et al. 1989).

Some investigators have postulated that if PL cells are osteogenic, then the bone phenotype must be blocked, otherwise the PL would spontaneously undergo bone formation, mineralize across its width and become ankylosed (Roberts and Chase 1981). 
Ogiso et al. (1991) demonstrated in vitro that PL cells could indeed inhibit mineralized bone nodule formation in rat bone stromal cells. This indicated that PL cells can control the extent of osteogenesis in physiological remodeling of the periodontium. The authors further suggested prostaglandin production as a possible cause for the PL cell inhibition of mineralization. This information supports preservation or stimulation of PL cells after trauma to prevent bone formation and subsequent ankylosis.

Lekic et al. (1996b) also noted that the relative numbers of osteogenic progenitor cells with the capacity for division and self-renewal appeared to be limited. The authors proposed that since fibroblast and osteoblast precursors are mixed in the PL, the fibroblast population could block the expression of osteogenic phenotype cells. Melcher (1970) proposed that the collagen fibres of the PL could also provide a physical barrier to osteogenesis. He also observed that where PL had been removed, callus proliferated into the wound. This is further evidence that cells of the PL possess the capacity to resist induction of osteogenesis. Physical removal of the PL of monkey teeth before experimental replantation led to extensive ankylosis (Andreasen and Kristerson 1981). This further suggests that PL progenitor cells are essential for the repopulation of the PL as well as control of osteogenesis. The damage caused by avulsion profoundly affects the PL that is adherent to the root and the consequences of extraoral storage and duration on this portion of the PL directly affects healing outcomes.

\section{Cellular Response to Acute Trauma}

\section{Pre-Replantation Duration and Storage}

Immediate replantation ( $\leq 5$ minutes) is the most important factor for PL regeneration and repair. This is due to reduction of damage to the PL during storage (Andreasen et al. 1995d). Avulsion can produce three main types of PL injury: drying, removal of PL and cementum from the root surface and compression (Andreasen and Kristerson 1981). The two most important variables to affect survival of replanted permanent incisors are duration of the extra-alveolar period and extra-alveolar storage (Andreasen et al. 1995d). Even drying less than 15 minutes produces severe loss of isolated PL cells and a decrease in their ability to reproduce (Andreasen et al. 1995d; 
Lekic et al. 1998). After 120 minutes of desiccation, no viable cells remain on the root surface (Söder et al. 1977; Lekic et al. 1998). A histological outcome study of lateral incisors from 8 monkeys suggested that 30-40 minutes may be the limit of drying to avoid severe root resorption as early as 8 weeks after replantation (Blomlöf et al. 1983).

The clonogenic capacity of PL cells is an in vitro measure of the proportion of progenitor cells with proliferative and colony-forming capacities within a larger cell population (Lekic et al. 1996a). This is closely linked to the ability of PL progenitor cells to attach and recolonize the root surface following replantation (Lekic et al. 1996a). In human teeth, in vitro experiments indicate that the critical period for severe cell damage from desiccation begins prior to 15 minutes (Lekic et al. 1998).

Lekic et al. (1998) showed that human PL cells stored in chilled $\left(4^{\circ} \mathrm{C}\right)$ Eagle's medium ( $\alpha$-MEM, culture medium) had the least reduction in clonogenic capacity at 30 and 60 minutes. At both 30 and 60 minutes, milk was shown to be equivalent to balanced salt solution (BSS) for retention of the cells' ability to reproduce. Although the greatest reduction in clonogenic capacity between 30 and 60 minutes was for cells stored in the patient's own saliva, saliva was acceptable as a storage medium up to 30 minutes.

Previously, Lekic et al. (1996a) noted improved cell viability for PL cells stored for 30-60 minutes in milk compared with those allowed to desiccate. Milk may have a cytoprotective effect due to its physiological osmolality, nutrient constituents and $\mathrm{pH}$ buffering system. Cooler temperatures $\left(4^{\circ} \mathrm{C}\right)$ of the storage medium have also been shown to slow reduction of the clonogenic capacity of PL cells (Lekic et al. 1996a). With cooler temperatures there is decreased cell expansion and increased cell viability (Lekic et al. 1996a).

Storage of PL cells in saliva and diluted Eagle's medium results in marked cell swelling (Blomlöf and Otteskog 1980). This indicates that the osmolality of saliva is too low for prolonged ( $>30$ minutes) cell storage. For PL cells stored in milk for 120 minutes, there was no significant cell swelling observed which suggested that the osmolality of milk is well tolerated by cells (Blomlöf and Otteskog 1980). Oikarinen and Seppä (1987) demonstrated that storage of human PL cells in milk for one hour did not markedly 
decrease proliferation. They also suggested that PL cells of avulsed teeth preserved in milk may still proliferate after 8 hours.

Blomlöf and Otteskog (1980) found Eagle's medium to improve cell survival compared with storage in milk, which indicates that the composition of the storage medium is important in addition to its osmolality. Lindskog and Blomlöf (1982) found negligible differences in cell viability and membrane morphology for cells stored in solutions with an isotonic osmolality such as Eagle's medium, isotonic saline and milk regardless of storage time. They also found that the composition of the storage media was of minor importance for cell viability and membrane integrity after storage up to 3 hours if the media had a physiologic osmolality.

Although immediate replantation is most desirable, the optimal storage medium for an avulsed tooth would be the tissue fluid of the PL. Blomlöf et al. (1983) investigated this using 15 monkey teeth, where the extracted teeth were wrapped and stored in a plastic foil for 60 minutes to prevent evaporation of the PL tissue fluid. The amount of resorption observed on these teeth was comparable to teeth that were immediately replanted. This observation and previous studies on the effects of desiccation on PL cells of the root surface indicates that the prevention of evaporation of tissue fluid from the PL must be considered a primary goal of maintaining an avulsed tooth that cannot be immediately replanted. Teeth that were allowed to air dry for 60 minutes demonstrated radiographic evidence of inflammatory resorption on almost all root surfaces. When the PL cells were cultured in vitro, little cell damage was observed for cells maintained in a humid atmosphere whereas cells stored in ambient conditions were non-viable (Blomlöf et al. 1983).

\section{Pre-Replantation Contamination}

Lindskog and Blomlöf (1982) noted the adherence of bacteria to the surface membrane of PL cells stored in saliva. This is important because of the lytic effect of bacterial enzymes and toxins (Lindskog and Blomlöf 1982). However, based upon a single study, cleansing the root surface of the avulsed tooth with saline prior to replantation appeared to have a negative effect on PL healing (Andreasen et al. 1995d). 
Socket and root surface contamination have not been properly investigated. Although gross removal of contaminants is a principle of wound management, clinicians lack guidance for minimally invasive means of root and socket decontamination and disinfection and their effects on clinical outcomes.

\section{Post-Replantation Sequelae}

PL healing can occur from the adjacent alveolar bone marrow portion of the PL. When nonvital PL is present, inflammatory resorption may occur more slowly than if the PL has been removed. The nonvital PL must first be removed and this slows resorption of the root surface (Andreasen and Kristerson 1981). Loss of PL progenitor cells will eventually lead to root resorption and healing by repair rather than regeneration following replantation (Lekic et al. 1996a).

\section{Long Term Effects of PL Wound Healing}

Two types of pathological root resorption occur after replantation: inflammatory and/or replacement resorption. Inflammatory resorption produces rapidly progressive bowl-shaped areas of resorption of cementum and dentin due to inflamed periodontal tissues. Replacement resorption produces direct union between alveolar bone and the root, ankylosis, with the loss of PL. Replacement resorption may ultimately cause the entire root to be resorbed, remodeled, and replaced by alveolar bone (Andreasen and Hjørting-Hansen 1966b). Radiographically, loss of lamina dura is an early sign that is followed by the eventual transformation of root tissue into bone. Teeth that are immobile indicate that greater than $10 \%$ of the root surface is ankylosed, whereas a characteristic resonant tone indicates that greater than $20 \%$ of root surface is ankylosed (Andersson et al. 1984). Transient replacement resorption and alterations in mobility may occur. These areas of minor ankylosis may be resorbed during rapid repair of the periodontium and normal mobility may return within 3 weeks of replantation (Andreasen and HjørtingHansen 1966b; Andreasen and Kristerson 1981) 


\section{Guidelines for Management}

The American Association of Endodontists (AAE) guidelines (1995) for treatment of avulsed permanent teeth recommend immediate replantation. There is cellular evidence to support immediate ( $\leq 5$ minutes) replantation (Blomlöf et al. 1983; Lekic et al. 1996a) and to identify desiccation as the prime cause of root surface cell death (Söder et al. 1977; Lekic et al. 1996a). By 30 minutes extra-alveolar time, Lekic et al. (1998) were able to demonstrate complete loss of the PL cells' ability to reproduce and both Söder et al. (1977) and Lekic et al. (1998) showed complete cell death by desiccation by 120 minutes. The patient's own saliva is an acceptable means of prevention of desiccation for up to 30 minutes (Lekic et al. 1998). However, Lekic et al. (1996a) also showed that cold milk is equivalent to cold BSS in its ability to maintain PL cell clonogenic capacity for up to 60 minutes. Beyond 60 minutes the cellular evidence is based upon cell vitality studies and outcome studies in animals and humans. Root PL cells of teeth that have not been immediately replanted have usually been exposed to a period of desiccation, a period of wet storage and perhaps a water rinse to remove contaminants. If the root appears clean, it can be rinsed with water or saline and replanted. On the other hand, storage in water is more apt to destroy cells than desiccation (Lekic et al. 1996a).

\section{Statement of the Problem}

Fibroblasts are the predominant cell type in the PL of humans and they play a central role in regeneration and repair following traumatic injury to teeth. Deletion of fibroblasts from the healing root surface after injury is thought to be important in the development of ankylosis, a condition in which fusion of the tooth root to bone occurs. Ankylosis is a common outcome following replantation of avulsed teeth. Currently, it is not known if the types of cells that are adherent to the healing root surface exert a direct influence on the outcome of healing and the prevention of ankylosis. Further, it is unknown whether the phenotype of the adherent cells affects the likelihood of restoration of a functional PL following injury. 


\section{Hypothesis}

Phenotypes of fibroblastic cells adherent to the root surface are affected by the storage conditions of the tooth after extraction/avulsion so that prolonged extra-alveolar time and dry storage selects for cells with phenotypic characteristics of osteogenic cells.

\section{Objectives}

1) To assess the phenotypic expression of two osteogenic markers (osteopontin and alkaline phosphatase) and of three fibroblastic markers (type III and XII collagens and $\alpha$-smooth muscle actin) in early passage human PL cell cultures.

2) To assess whether the phenotype of cells derived from extracted roots and stored in "wet" or "dry" conditions for 30 or 120 minutes is changed by the storage conditions.

\section{Rationale}

Fibroblasts are the predominant cell type of the human PL and other mammals and they play a central role in normal turnover, regeneration and repair following injury to periodontium. Severe injury to the PL due to avulsion leads to massive death of PL fibroblasts and other cells adherent to the root surface (Andreasen 1981a). In response to this injury, various reactive sequelae may occur that include cell proliferation, migration and differentiation as integral components of regeneration and repair. It is thought that recolonization of the PL space by locally proliferating PL fibroblasts favours restoration of a fibrous attachment while recolonization by osteogenic cells from alveolar bone leads to loss of PL and ingrowth of bone that results in tooth ankylosis (Melcher 1970). Ankylosis can be experimentally induced by disruption of the mechanisms that maintain the spatial domains of cell populations required for the formation of bone, cementum, and PL fibres (Line et al. 1974; Lekic et al. 1997). However, the mechanisms utilized by PL cell populations to restore and maintain their cellular domains after injury or application of heavy applied forces is unknown (Lekic et al. 1996c). The study of mechanisms that regulate domain function is further complicated by the heterogeneous nature of the fibroblast populations of the PL (Narayanan and Page 1983; McCulloch and Bordin 1991) and the current lack of studies that use markers to identify these populations. 
Cell markers are proteins that can be used to identify specific cell types or cell lineages. For example the expression of epidermal growth factor receptor (Cho et al. 1991), type XII collagen (Oh et al. 1993; Karimbux and Nishimura 1995), osteopontin (Lekic et al. 1996b) and alkaline phosphatase (Groeneveld et al. 1993) have been used to identify discrete populations of fibroblasts in the PL that may be associated with various functions or stages of cell differentiation. Notably, the ability to discriminate the fibrogenic and osteogenic populations in the PL and to study their regulation could be useful for studies of repair phenomena including ankylosis. However, there has been relatively little exploration of the nature of repopulating cells after injury to the periodontium, a gap in knowledge that may be important to the understanding of domain regulation in the PL and cell types that determine the outcome of reparative processes (e.g. ankylosis).

There are a variety of in vivo and in vitro model systems for characterization of fibroblast subpopulations (Bordin et al. 1984) that can be applied to the investigation of periodontal injury (Gould et al. 1980; Lekic et al. 1996a). In vitro model systems provide an opportunity to study cell function and differentiation in a regulated environment. However, in order to obtain large enough cell numbers, prolonged growth and repeated passaging can increase the likelihood of in vitro artefacts and cell selection effects. Indeed, significant phenotypic and proliferative changes may occur in selected cell populations of multiple passage cultures. As a consequence, the cultures themselves may no longer reflect the nature of the original cell population that was cultured (Narayanan and Page 1983; McCulloch and Knowles 1991). In contrast, analysis of early passage cultures minimizes selection effects but provides relatively few cells for analysis.

This study utilized single cell immunohistochemical analysis of several intracellular protein markers to characterize the phenotypes of human PL fibroblasts. These markers were chosen on their predicted ability to discriminate PL-associated cells that may give rise to either osteogenic or fibrogenic cells. Cells from early passage cultures grown from single cell suspensions of PL tissue were examined to test the hypothesis that the phenotypes of the recolonizing cells on root surfaces subjected to severe injury (i.e. extraction) are affected by the storage conditions of the tooth after extraction. Conceivably in vivo, the nature and 
extent of the injury may profoundly affect the cell repopulation of healing wounds and ultimately, the nature of the reparative response. 


\section{Material and Methods}

\section{Cell Culture}

Premolar teeth extracted for orthodontic purposes $(n=15)$ were obtained from 6 human subjects (10-14 years) after informed consent was obtained from patients and parents. All teeth were fully erupted, the gingiva was healthy, and periodontal pockets were $<3 \mathrm{~mm}$. An elevator and forceps were used to extract the teeth with minimal trauma to the root surface. After extraction, the teeth were washed and maintained in $\alpha$-MEM containing $0.17 \%(\mathrm{v} / \mathrm{v})$ antibiotics at $4^{\circ} \mathrm{C}$ for 30 or 120 minutes ("wet") or left in air ("dry") for 30 or 120 minutes. Desiccation for 30 to 120 minutes approximates a common clinical condition observed following tooth avulsion (Barrett and Kenny 1997) and indeed 30 minutes is thought to be the maximum time replanted teeth can remain outside of the alveolar socket and still exhibit regeneration of new PL cells. PL cells were obtained 30 or 120 minutes after initiation of storage by scraping the PL tissue from the entire root surface with great care to avoid inclusion of gingival tissues. PL cells were released from the scraped samples by a 30 minute enzymatic digestion [ $0.05 \%$ trypsin and $0.15 \%$ collagenase; (Lekic et al. 1996a; Lekic and McCulloch 1996) Sigma, St. Louis, MO]. Single cell suspensions were prepared and cultured on tissue culture plastic flasks (T-25 or T-75; Falcon, Mississauga, $\mathrm{ON})$ in $\alpha$-MEM containing $10 \%(\mathrm{v} / \mathrm{v})$ fetal bovine serum for one week and subcultured at a split ratio of 1:3 for up to 3 passages. At each passage, an aliquot of cells was plated into 8well chamber slides for immunohistochemical assessment. Immunofluorescence localization of marker proteins was performed directly in the chamber slides for passages \#2 or \#3.

\section{Immunofluorescence}

Cells plated on glass slides were incubated for 3 days at $37^{\circ} \mathrm{C}$, fixed in $2 \%(w / v)$ paraformaldehyde for 1 hour at room temperature and rinsed with phosphate buffered saline (PBS) without calcium or magnesium. A blocking solution of mouse or rabbit whole serum (1:1000 dilution) in bovine serum albumin (BSA; Sigma, 2\% v/v in PBS) was applied for 2 hours at room temperature. Immunofluorescence staining for nebulin (Sigma, clone \#NB2), $\alpha$-smooth muscle actin (Sigma, clone \#1A4), and type XII collagen (Neomarkers, Fremont, $\mathrm{CA}$ ) were performed with mouse monoclonal antibodies (1:50 dilution in 2\% BSA/PBS), 
while staining for osteopontin (LF-123), type III collagen (LF-70), and alkaline phosphatase (LF-47) were performed with rabbit antibodies obtained from Dr. Larry Fisher (NIDR, Bethesda, MD; Fisher et al. 1995; 1:50 dilution in 2\% BSA/PBS) for 1 hour at room temperature. Samples were rinsed with $2 \% \mathrm{BSA} / \mathrm{PBS}$ followed by a FITC-conjugated goat anti-mouse or FITC-conjugated goat anti-rabbit antibody (1:200 dilution in 2\% BSA/PBS) for 1 hour at room temperature. To stain nuclei, cells were incubated with DAPI $(1 \mu \mathrm{g} / \mathrm{ml}$ in $0.1 \% \mathrm{v} / \mathrm{v}$ Triton $\mathrm{X}-100$ ) for 10 minutes at room temperature. Non-specific control staining was evaluated on the same slide by incubating cells with secondary antibody only.

A number of phenotypic markers were examined in order to estimate whether the cultured cells from the PL exhibited a predominantly fibrogenic or osteogenic differentiation pathway in vitro. For assessment of the fibrogenic pathway, it was considered that type III collagen is expressed by PL fibroblasts and by stromal mesenchymal cells but is not generally expressed by functional osteoblasts (Wang et al. 1980). Type III collagen is also present at very low levels in the gingival fibroblast lines examined and they provide a useful negative control to assess the specificity of staining. For more precise description of a PL fibroblast, it was noted that Karimbux et al. (1992) have shown that type XII collagen expression may be temporally related to the collagen fibrillogenesis stage during PL development and that type XII collagen is expressed by PL but not gingival cells. For assessment of the possible contractile function of fibrogenic and osteogenic cells, actin expression was examined. $\beta$-actin is the most abundant actin isoform in gingival and PL fibroblasts (Arora and McCulloch 1994) and comprises up to $80 \%$ of total cellular actin while $\alpha$-smooth muscle actin is a much less abundant isoform $(<20 \%$ of total actins in fibroblasts) that is expressed in smooth muscle cells and at higher levels in myofibroblasts (Desmoulière et al. 1993). The $\alpha$-smooth muscle actin isoform is typically incorporated into stress fibres of cells that are engaged in contraction, in particular, the remodeling of collagen by traction (Arora and McCulloch 1994). To assess the osteogenic differentiation pathway in the PL cells obtained from root surface cultures, osteopontin and alkaline phosphatase were examined. Osteopontin is an abundant protein in secretions such as tears and milk and is found in high levels at the remodeling sites of bone (McKee and Nanci 1996) but only transiently at the interfaces of wound surfaces in the PL (Lekic et al. 1996c). 
Alkaline phosphatase is an ectomembrane protein that is expressed by mineralized tissueforming cells (Fedarko et al. 1990). Although alkaline phosphatase expression is not specific for cells of the osteoblast lineage, osteogenic cells are rich in this enzyme and alkaline phosphatase-positive cells are localized to areas of in vitro bone nodule formation (Maniatopoulos et al. 1988). While alkaline phosphatase is expressed by PL cells (Groeneveld et al. 1993), it is more strongly expressed in osteogenic cells (Inoue et al. 1992).

Cells were examined with a fluorescence microscope and photometer (Orthoplan, Leica, Wetzlar, Germany) with appropriate filters for DAPI and FITC. Cells were photographed with T-MAX film (Kodak; 3200 ASA). The length of exposure was optimized for positive controls and all subsequent photographs for each antibody used this same exposure time so that the relative brightness of staining would be preserved in the photomicrographs. The fluorescence intensity of all cells that were photographed was estimated with a microscope photometer (Leica) and these data were used as a quantitative estimate for brightness analysis ( $n=3$ samples per group; each sample represents at least 3 cells per field). 


\section{Results}

Validation of Methods

Prior to analyzing test specimens, the sensitivity and specificity of the immunohistochemical reactions and the antibodies used for assessment of fibroblastic and osteogenic cell markers were evaluated by staining cells that were known to express (or not) the protein of interest. Negative controls for alkaline phosphatase, osteopontin and type XII collagen employed human gingival fibroblasts as there are no convincing reports that show high level expression of any of these proteins by gingival fibroblasts. As expected, no staining for these proteins was observed in gingival fibroblasts (Figure 1) although they were slightly brighter than the irrelevant mouse antibody isotype control (anti-nebulin, a protein that is not expressed in fibroblasts). Positive controls for alkaline phosphatase and osteopontin employed rat bone marrow stromal cells since the antibodies used in this investigation are known to react with rat osteogenic cells and rat bone marrow stromal cells are known to express these proteins (Aubin 1999). Further, rat bone marrow stromal cells can form mineralized tissue in vitro (Maniatopoulos et al. 1988), which indicates that this population contains some osteogenic cells. Rat bone marrow stromal cells stained brightly for alkaline phosphatase and osteopontin as anticipated (Figure 1). For type XII collagen, human PL cells and gingival fibroblasts were examined. Again as expected (Karimbux et al. 1992), gingival fibroblasts showed no positive staining while the PL cells were brightly stained. Taken together, these data indicated that the immunostaining reactions were sensitive and specific for the cells examined here. 
Table 1. Estimates of fluorescence intensity for intracellular periodontal cell markers

Left: Fluorescence intensity given in fluorescence units $\left([1 / \mathrm{T}] \times 10^{+}\right)$where $\mathrm{T}$ is the time (seconds) recorded by the microscope photometer to achieve uniform photon counts between images. The data are mean \pm standard error of the mean. Right: Estimates of visual brightness seen in microscope; +++indicating greatest brightness and - indicating the least brightness.

\begin{tabular}{|c|c|c|c|c|c|c|c|c|}
\hline Marker & \multicolumn{2}{|c|}{ Wet 30 mins } & \multicolumn{2}{|c|}{ Wet 120 mins } & \multicolumn{2}{|c|}{ Dry 30 mins } & \multicolumn{2}{|c|}{ Dry 120 mins } \\
\hline Type III Collagen & $185 \pm 37$ & ++ & $175 \pm 24$ & + & $250 \pm 48$ & + & $182 \pm 46$ & $H$ \\
\hline $\begin{array}{l}\text { Type XII } \\
\text { Collagen }\end{array}$ & $222 \pm 59$ & ++ & $226 \pm 88$ & + & $178 \pm 34$ & + & $137 \pm 16$ & - \\
\hline $\begin{array}{l}\alpha \text {-smooth muscle } \\
\text { actin }\end{array}$ & $292 \pm 42$ & ++ & $574 \pm 228$ & $+H$ & $768 \pm 482$ & ++++ & $450 \pm 50$ & ++ \\
\hline Osteopontin & $159 \pm 26$ & + & $194 \pm 27$ & + & $195 \pm 40$ & ++ & $244 \pm 44$ & + \\
\hline $\begin{array}{l}\text { Alkaline } \\
\text { Phosphatase }\end{array}$ & $187 \pm 41$ & + & $244 \pm 44$ & + & $328 \pm 43$ & ++ & $305 \pm 28$ & ++ \\
\hline
\end{tabular}

For each sample group, $n=3$ separate samples. One-way analysis of variance showed that there were no statistically significant differences between treatment groups within each protein that was examined ( $p>0.2)$. 


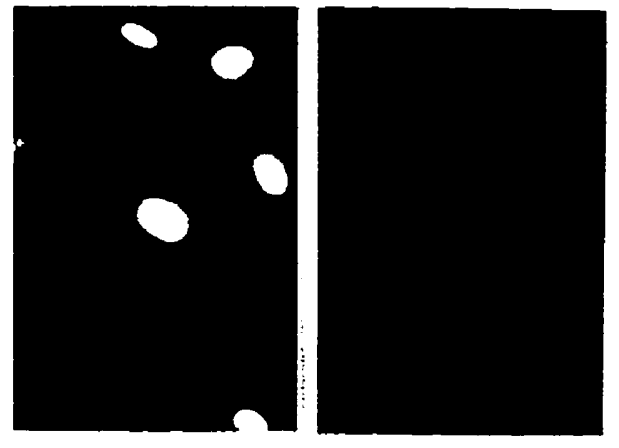

NEBULIN
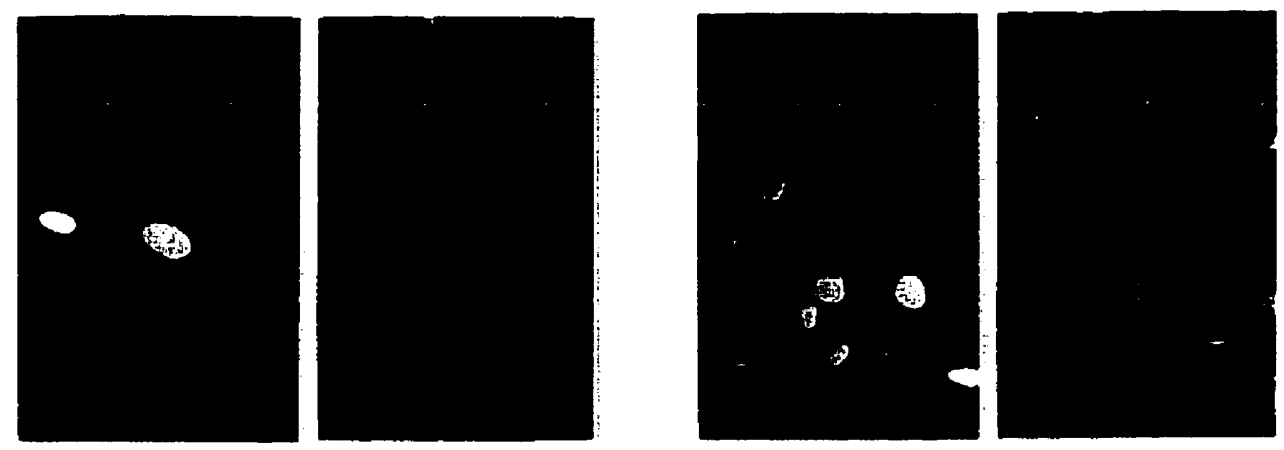

TYPE III

COLlaGEN
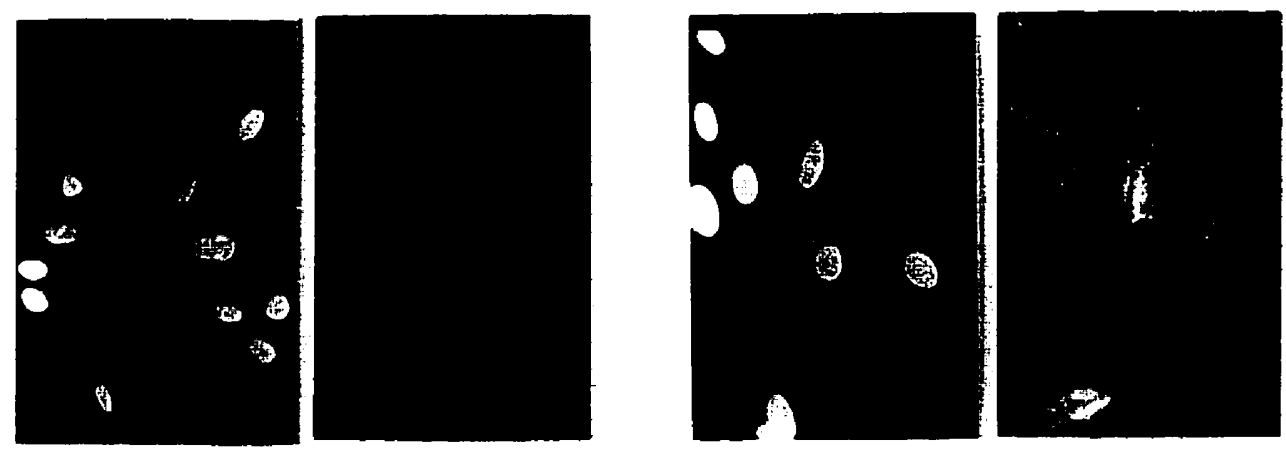

TYPE XII

COLLAGEN

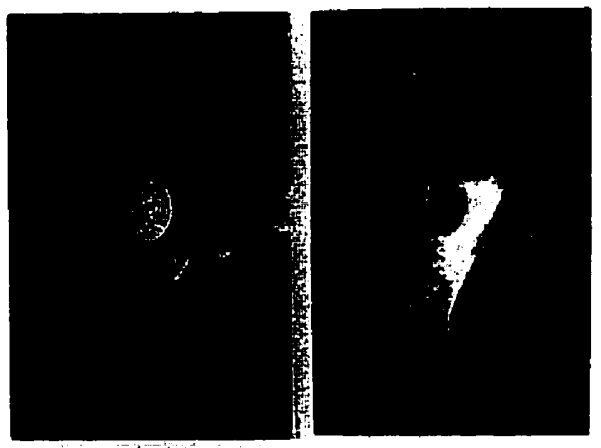

OSTEOPONTIN
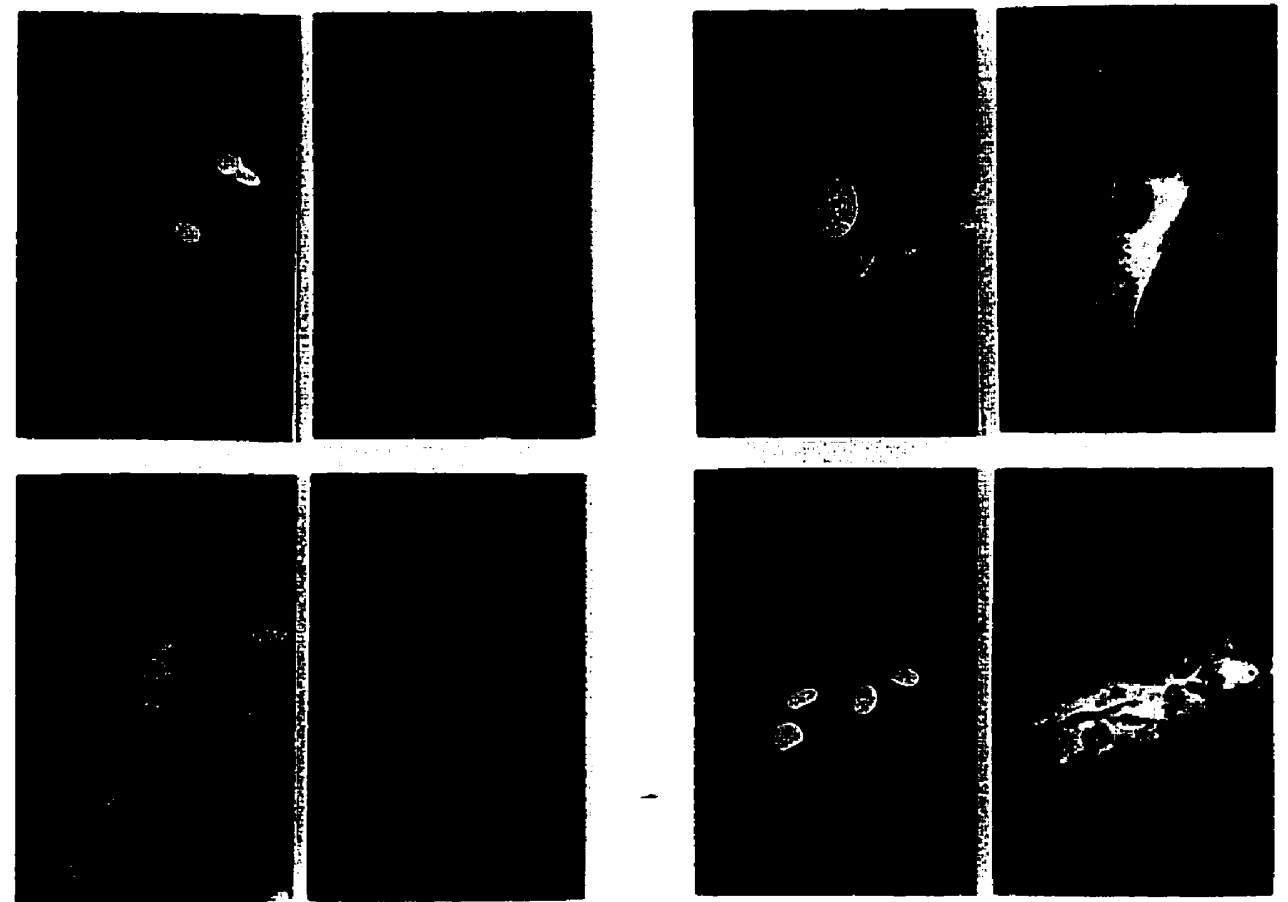

ALKALINE PHOSPHATASE

POSITIVE

NEGATTVE CONTROLS CONTROLS 
Figure 1 Validation of Methods - Immunohistochemical Staining Patterns for Negative and Positive Controls.

Nebulin: immunofluorescent staining with an irrelevant isotype control antibody in human PL cells and a FITC-labelled anti-mouse secondary antibody. Minimal staining is visible for nebulin. Type III collagen: gingival fibroblasts showed minimal staining as expected (negative control) while rat bone marrow stromal cells which contain a mixture of different cell types showed moderate staining as positive controls. Type XII collagen: human gingival fibroblasts used as negative controls demonstrate no visible staining while human PL cells (positive control) show strong staining. Osteopontin: human gingival fibroblasts (negative control) show much weaker staining than rat bone marrow stromal cells (positive control). Alkaline phosphatase: human gingival fibroblasts and rat bone marrow stromal cells used as negative and positive controls respectively. Magnification: 135X. 


\section{Type III Collagen}

As expected, there was positive staining for type III collagen in PL fibroblasts but very low levels of staining in the gingival fibroblast cell line that is known to exhibit very low levels of type III collagen synthesis and is used here as a negative control (Figure 1). Incubation of extracted teeth in the 4 different test conditions produced no large change in the pattern of staining for type III collagen (Figure 2). The staining appeared to be slightly more intense in the samples stored in dry conditions (30 minutes) which was in agreement with the slightly increased brightness recorded by the microscope photometer (Table 1). 
Figure 2 Staining of Type III Collagen in Human PL Cells.

Immunohistochemical staining for type III collagen in human PL cells stored in the 4 indicated conditions: (A) 30 minute wet storage - perinuclear staining; (B) 30 minute dry storage - no change in pattern of staining but appears more intense than 30 minute wet conditions; (C) 120 minute wet storage - no change in staining pattern (perinuclear); (D) 120 minute dry storage - staining appears more intense than in wet samples. Magnification $250 \mathrm{X}$. 


\section{Type XII Collagen}

Consistent with the report of Karimbux et al. (1992), it was observed that PL fibroblasts but not gingival fibroblasts expressed type XII collagen (Figure 1). Further, there were marked differences in the pattern of staining after storage in wet or dry conditions. In the samples stored in wet conditions, the staining was perinuclear and reminiscent of Golgi staining as would be expected for a secreted protein, whereas in the 30 minute dry condition, staining was restricted to isolated foci in the cytoplasm (Figure 3). In the 120 minute dry samples, the staining was weak and exhibited no specific pattern. The staining intensity for this condition was similar to that of gingival fibroblasts that do not express type XII collagen. The reduced fluorescence for the dry samples obtained by photometry is consistent with the decreased expression of this marker (Table 1). 
Figure 3 Staining of Type XII Collagen in Human PL Cells.

Immunohistochemical staining for type XII collagen in human PL cells for the 4 indicated conditions: (A) 30 minute wet storage - perinuclear pattern of staining consistent with Golgi staining; (B) 30 minute dry storage - staining restricted to isolated foci in the cytoplasm; (C) 120 minute wet storage - no change in pattern of staining from 30 minute wet sample; (D) 120 minute dry storage - no specific pattern of staining and appeared weak in comparison to 3 other sample conditions. Magnification 250X. 


\section{$\alpha$-Smooth Muscle Actin}

There was a perinuclear or Golgi type of staining distribution in cells that had been stored in cell culture medium for 30 minutes that suggested $\alpha$-smooth muscle actin was not incorporated into stress fibres and that the cells were not particularly contractile (Figure 4). In the 120 minute wet sample, some small diameter stress fibres were visible while in the dry samples, stress fibres were very prominent. Fragments of cytoplasmic processes were also visible in some of the dry samples possibly indicating the retraction of highly contractile cells during spreading over the culture dish surface during sample preparation. The increase of fluorescence brightness recorded by the microscope photometer for the dry samples compared with the 30 minutes wet sample also suggests increased expression of $\alpha$ smooth muscle actin as a result of dry storage conditions (Table 1 ). 
Figure 4 Staining of $\alpha$-Smooth Muscle Actin in Human PL Cells.

Immunohistochemical staining for $\alpha$-smooth muscle actin in human PL cells for the 4 indicated conditions: (A) 30 minute wet storage - perinuclear, Golgi staining; (B) 30 minute dry storage - more intense staining of stress fibres and cytoplasmic processes; (C) 120 minute wet storage - intense staining of some small diameter stress fibres; (D) 120 minute dry storage - stress fibres and cytoplasmic fragments are intensely stained. Magnification $250 X$. 


\section{Osteopontin}

As a secreted protein, intracellular osteopontin would be expected to be prominent in the Golgi apparatus and secretory vesicles. Consistent with this expectation it was noted that the pattern of staining was localized to Golgi apparatus and secretory vesicles. Staining was more intense in cells stored in dry conditions (Figure 5). Notably, the 120 minute dry samples appeared to have a different distribution in which the protein was restricted to isolated bright spots, reminiscent of the focal adhesion staining for osteopontin reported earlier in migrating osteogenic cells (Zohar et al. 1997). Similar to $\alpha$-smooth muscle actin, the dry samples had increased fluorescence intensity that indicated higher levels of expression of osteopontin in these samples (Table 1). 
Figure 5 Staining of Osteopontin in Human PL Cells.

Immunohistochemical staining for osteopontin in human PL cells for the 4 indicated conditions: (A) 30 minute wet storage - perinuclear staining consistent with staining of Golgi and secretory vesicles; (B) 30 minute dry storage - no change in pattern of staining, but staining appeared more intense; (C) 120 minute wet storage - pattern of staining remains the same, but staining appeared less intense than 30 and 120 minute dry; (D) 120 minute dry storage - staining appeared restricted to isolated bright spots similar to pattern of focal adhesion staining in migrating osteogenic cells. Magnification 250X. 


\section{Alkaline Phosphatase}

Staining was primarily restricted to cell surfaces in both wet and dry samples. There was more intense staining in the samples stored under dry conditions than wet conditions (Figure 6). This observation is supported by the increased fluorescence intensities (Table 1). 
Figure 6 Staining of Alkaline Phosphatase in Human PL Cells.

Immunohistochemical staining for alkaline phosphatase in human PL cells for the 4 indicated conditions: (A) 30 minute wet storage - extracellular pattern of staining; (B) 30 minute dry storage - no change in pattern of staining, but appeared more intense than 30 and 120 minute wet storage conditions; (C) 120 minute wet storage - no observable change to pattern of staining; (D) 120 minute dry storage - more intense extracellular pattern of staining. Magnification 250X. 


\section{Discussion}

Storage conditions of extracted teeth exert a profound effect on the phenotype of cells cultured from remnants of the PL attached to the root surface. The present investigation utilized a novel approach to study PL cell differentiation which involved intracellular staining of several fibrogenic and osteogenic markers that were examined in early passage cells cultured from the PL of extracted human teeth. There was evidence of increased staining for osteopontin, alkaline phosphatase and $\alpha$-smooth muscle actin, but decreased staining for type XII collagen after prolonged dry storage. These data indicate that dry storage favours the in vitro growth of contractile osteogenic cells at the expense of PL fibroblasts and suggests a mechanism by which prolonged extra-alveolar storage not only encourages the differentiation of osteogenic cells associated with the root surface but also causes the selective loss of fibrogenic PL cells. In this context fibrogenic PL cells are thought to be involved in preservation of the PL space (Melcher 1970; Line et al. 1974). These data are consistent with clinical reports that show prolonged extra-alveolar storage of avulsed teeth prior to replantation increases the risk of ankylosis (Andreasen 1981a), a condition in which the PL space is colonized by osteogenic cells and is replaced by bone. Taken together with a previous report that showed prolonged extra-alveolar time greatly decreased the clonogenic capacity of PL cells while exerting much less of an effect on cell viability (Lekic et al. 1996a), these results suggest that desiccation and storage-related damage to PL cells strongly encourages the growth and differentiation of osteogenic cells that then colonize the PL space and produce ankylosis. Thus, while the current concept of ankylosis is based on recolonization of the PL space by osteogenic cells originating from the alveolar bone (Lekic et al. 1997), these current data suggest that unfavourable storage conditions after extraction/avulsion (i.e. desiccation) also encourage the growth and differentiation of osteogenic cells from the root side of the PL and the selective loss of PL fibroblasts (e.g. loss of type XII collagen staining). One particular point of interest was the increased expression of osteopontin with longer periods of dessication on storage. As osteopontin is an adhesive glycoprotein for osteoclast attachment as well a regulator of mineralization (McKee and Nanci 1996), the increased expression of osteopontin suggests a 
mechanism by which osteoclastic and dentinoclastic cells could more avidly attach to tooth surfaces and cause root resorption.

Although these data are of clinical interest in the context of tooth avulsion injuries and regeneration of the PL, their interpretation is dependent upon the validity of the model system. Studies of PL healing after injury have often used in vitro and in vivo model systems, experimental approaches that can provide insight into biological mechanisms in a more efficient manner than human clinical studies. In vitro models typically employ homogeneous cell populations that can be analyzed under rigorously controlled conditions that are independent of in vivo factors. In this study, the independent experimental variables were based on conditions using "wet" and "dry" tooth storage. This is similar to previous studies which compared the effect of various storage media and the duration of the extraalveolar time on the survival of PL cells (Andersson et al. 1989; Blomlöf and Otteskog 1980; Lekic et al. 1998; Söder et al. 1977). While previous in vitro studies of PL cell function used rodent (Lin et al. 1994) or primate cells (Andreasen 1981a), the use of human PL cells may provide a more suitable model to assess the critical variables that affect cell viability (Lekic et al. 1996a) and ultimately treatment outcomes. Further, the study of cells in very early passage cultures obviates artefacts due to cell selection effects associated with high passage cultures (Narayanan and Page 1983).

While incisors are the most commonly avulsed teeth (Andreasen and HjørtingHansen 1966a), this study examined PL cells from premolar teeth. Although there are minor differences of cellular phenotypes in situ between different tooth types, these differences were undetectable using the analytical methods reported here and elsewhere with other methods (Lekic et al 1996a; Lekic et al. 1998). Consequently, there are insufficient data to suggest that the study of premolars instead of incisors has undermined the general validity of the experiments.

Current clinical guidelines of the American Association of Endodontists (1995) recommend that avulsed teeth should be replanted immediately if possible. These suggestions are based on both animal and clinical studies (Andreasen 1981a; Andreasen et al. 1995a; Andreasen et al. 1995b; Andreasen et al. 1995c; Andreasen et al. 1995d). Consistent with these data, results of this investigation indicate that desiccation of avulsed 
teeth should be minimized to optimize the maintenance of the PL fibroblast phenotype and possibly the regeneration of PL. These findings are in agreement with Lekic et al. (1996a) who found that the in vitro clonogenic capacity of PL cells is temporally associated with the ability of PL progenitor cells to attach and recolonize the root surface following replantation. Notably, the critical period for rapid loss of cell viability begins before 15 minutes extra-alveolar duration (Lekic et al. 1998).

The novel feature of this study is the attempt to phenotypically characterize the differentiation repertoire of adherent PL cells in vitro as a model to understand the mechanisms involved in repair of the injured PL, specifically following avulsions. An improved understanding of factors that regulate cell viability and differentiation of osteogenic and fibroblastic cells in the PL could lead to more rationale treatment approaches after injury to the periodontium. These approaches might include optimization of methods to promote the survival or stimulation of cells required for the regeneration and repair of the PL. The most common outcome for dental avulsions (PL repair or tooth loss) is due to complications that result from delayed replantation (Andreasen et al. 1995b; Barrett and Kenny 1997). If clinicians had the ability to modify PL cell differentiation they would have the means to promote regeneration over repair and return the replanted tooth to its pre-injury state.

There are several limitations of this investigation which include the relative lack of quantification of markers and the small sample size employed. Further studies are required to fully characterize the phenotype of PL cells following traumatic injury. Growth rates and the computation of population doubling levels for osteoprogenitor cells could be examined to determine if cells of the osteogenic phenotype are present in sufficient numbers to provide a case for ankylosis. The measurement of the number of mineralized bone nodules that would form in cultures containing an organic phosphate and dexamethasone would give a relative estimate of the relative proportion of osteogenic cells. It would also be of benefit to quantify the percentage of cells that express (or not) the specific markers used in this investigation. 


\section{Conclusions}

1) There is increased expression of bone markers (osteopontin and alkaline phosphatase) by PL-associated cells after storage in dry conditions between 30 and 120 minutes desiccation.

2) There is decreased expression of the PL fibroblast marker, type XII collagen, after storage of teeth in dry conditions for 120 minutes.

3) Dry conditions promote the increased expression of $\alpha$-smooth muscle actin and incorporation of this actin isoform into stress fibres, that indicate the preferential formation of contractile cells.

4) These data are consistent with clinical observations from previous studies that show increased extra-alveolar time and dry storage lead to increased bone formation and the likelihood of ankylosis (Andreasen 1981a; Andreasen et al.1995d; Lekic et al. 1998; Andreasen and Kristerson 1981; Söder et al. 1977). 


\section{Bibliography}

American Association of Endodontists: Recommended guidelines for the treatment of the avulsed permanent tooth. Chicago 1995.

Andersson L, Blomlöf L, Lindskog S, Feiglin B, Hammarström L: Tooth ankylosis: clinical, radiographic and histological assessments. International Journal of Oral Surgery 13:423$431,1984$.

Andersson L, Bodin I, Sörensen S: Progression of root resorption following replantation of human teeth after extended extraoral storage. Endodontics \& Dental Traumatology 5:38-47, 1989.

Andreasen JO: Effect of extra-alveolar period and storage media upon periodontal and pulpal healing after replantation of mature permanent incisors in monkeys. International Journal of Oral Surgery 10:43-53, 1981a.

Andreasen JO: Traumatic Injuries of the Teeth, $2^{\text {nd }}$ ed. Philadelphia, PA: WB Saunders Co. 203-271, 1981b.

Andreasen JO, Borum MK, Jacobsen HL, Andreasen FM: Replantation of 400 avulsed permanent incisors. 1. Diagnosis of healing complications. Endondontics \& Dental Traumatology 11:51-58, 1995a.

Andreasen JO, Borum MK, Jacobsen HL, Andreasen FM: Replantation of 400 avulsed permanent incisors. 2. Factors related to pulpal healing. Endondontics \& Dental Traumatology 11:59-68, 1995b. 
Andreasen JO, Borum MK, Andreasen FM: Replantation of 400 avulsed permanent incisors. 3. Factors related to root growth. Endondontics \& Dental Traumatology 11:69-75, 1995c.

Andreasen JO, Borum MK, Jacobsen HL, Andreasen FM: Replantation of 400 avulsed permanent incisors. 4. Factors related to periodontal ligament healing. Endondontics \& Dental Traumatology 11:76-89, 1995d.

Andreasen JO, Hjørting-Hansen E: Replantation of teeth. I. Radiographic and clinical study of 110 human teeth replanted after accidental loss. Acta Odontologica Scandinavica 24:263286, 1966a.

Andreasen JO, Hjørting-Hansen E: Replantation of teeth. II. Histological study of 22 replanted anterior teeth in humans. Acta Odontologica Scandinavica 24:287-306, $1996 \mathrm{~b}$.

Andreasen JO, Kristerson L: The effect of limited drying or removal of the periodontal ligament: periodontal healing after replantation of mature permanent incisors in monkeys. Acta Odontologica Scandinavica 39:1-13, 1981.

Arora P, McCulloch CAG: Dependence of collagen remodelling on $\alpha$-smooth muscle actin expression by fibroblasts. Journal of Cellular Physiology 159:161-175, 1994.

Aubin JE: Osteoprogenitor cell frequency in rat bone marrow stromal populations: role for heterotypic cell-cell interactions in osteoblast differentiation. Journal of Cellular Biochemistry 72(3):396-410, 1999.

Barrett EJ, Kenny DJ: Survival of avulsed permanent maxillary incisors in children following delayed replantation. Endodontics \& Dental Traumatology 13(6):269-275, 1997. 
Blomlöf L, Andersson L, Lindskog S, Hedström KG, Hammarström L: Periodontal healing of replanted mondey teeth prevented from drying. Acta Odontologica Scadinavica 41:117123, 1983.

Blomlöf L, Otteskog P: Viability of human periodontal ligament cells after storage in milk or saliva. Scandinavian Journal of Dental Research 88:436-440, 1980.

Bordin S, Page RC, Narayanan AS: Heterogeneity of normal human diploid fibroblasts: isolation and characterization of one phenotype. Science 223(4632):171-173, 1984.

Cho MI, Lin WL, Garant PR: Occurrence of epidermal growth factor-binding sites during differentiation of cementoblasts and periodontal ligament fibroblasts of the young rat: a light and electron microscopic radioautographic study. The Anatomical Record 231;14-24, 1991.

Desmoulière A, Geinoz A, Gabbiani F, Gabbiani G: Transforming growth factor $\beta 1$ induces $\alpha$-smooth muscle actin expression in granulation tissue myofibroblasts and in quiescent and growing cultured fibroblasts. Journal of Cell Biology 122(1):103-111, 1993.

Evans GS, Potten CS: Stem cells and the elixir of life. BioEssays 13(3):135-138, 1991.

Fedarko NS, Bianco P, Vetter U, Robey PG: Human bone cell enzyme expression and cellular heterogeneity: correlation of alkaline phosphatase enzyme activity with cell cycle. Journal of Cellular Physiology 144(1):115-121, 1990.

Fisher LW, Stubbs III JT, Young MF: Antisera and cDNA probes to human and certain animal model bone matrix noncollagenous proteins. Acta Orthopediadic Scandinavica (Suppl 266) 66:61-65, 1995. 
Gould TRL, Melcher AH, Brunette DM: Migration and division of progenitor cell populations in periodontal ligament after wounding. Journal of Periodontal Research 15:20$42,1980$.

Groeneveld MC, Everts V, Beertsen WA: A quantitative enzyme histochemical analysis of the distribution of alkaline phosphatase activity in the periodontal ligament of the rat incisor. Journal of Dental Research 72(9):1344-1350, 1993.

Hammarström L, Blomlöf L, Lindskog S: Dynamics of dentoalveolar ankylosis and associated root resorption. Endodontics \& Dental Traumatology 5:163-175, 1989.

Hiltz J, Trope M: Vitality of human lip fibroblasts in milk, Hanks balanced salt solution and Viaspan storage media. Endodontics \& Dental Traumatology 7(2):69-72, 1991.

Inoue T, Chen SH, Usuda J, Morohoshi Y, Shimono M: Osteogenic activity of cells from dental pulp, periodontal ligament, bone marrow and muscle in vitro: an ultrastructural study and alkaline-phosphatase activity. Bulletin Tokyo Dental College 33(1):7-12, 1992.

Karimbux NY, Nishimura I: Temporal and spatial expressions of type XII collagen in the remodeling periodontal ligament during experimental tooth movement. Journal of Dental Research 73(1):313-318, 1995.

Karimbux NY, Rosenblum ND, Nishimura I: Site-specific expression of collagen I and XII mRNAs in the rat periodontal ligament at two developmental stages. Joumal of Dental Research 71(7):1355-1362, 1992.

Lekic P, Kenny DJ, Barrett E: The influence of storage conditions on the clonogenic capacity of periodontal ligament cells: implications for tooth replantation. International Endodontic Journal 31-137-140, 1998. 
Lekic P, Kenny D, Moe HK, Barrett E, McCulloch CAG: Relationship of clonogenic capacity to plating efficiency and vital dye staining of human periodontal ligament cells: implications for tooth replantation. Journal of Periodontal Research 31:294-300, $1996 \mathrm{a}$.

Lekic P, McCulloch CAG: Periodontal ligament cell populations: the central role of fibroblasts in creating a unique tissue. The Anatomical Record 245:327-341, 1996.

Lekic P, Rubbino I, Krasnoshtein F, Cheifetz S, McCulloch CAG, Tenenbaum H: Bisphosphonate modulates proliferation and differentiation of rat periodontal ligament cells during wound healing. The Anatomical Record 247:329-340, 1997.

Lekic P, Sodek J, McCulloch CAG: Osteopontin and bone sialoprotein expression in regenerating rat periodontal ligament and alveolar bone. The Anatomical Record 244:50-58, 1996b.

Lekic P, Sodek J, McCulloch CAG: Relationship of cellular proliferation to expression of osteopontin and bone sialoprotein in regenerating rat periodontium. Cell and Tissue Research 285(3):491-500, 1996c.

Lin WL, McCulloch CAG, Cho MI: Differentiation of periodontal ligament fibroblasts into osteoblasts during socket healing after tooth extractionin the rat. The Anatomical Record 240:492-506, 1994.

Lindskog S, Blomlöf L: Influence of osmolality and composition of some storage media on human periodontal ligament cells. Acta Odontologica Scandinavica 40:435-441, 1982.

Line SE, Polson AM, Zander HA: Relationship between periodontal injury, selective cell repopulation and ankylosis. Journal of Periodontology 45:725-730, 1974. 
Maniatopoulos C, Sodek J, Melcher AH: Bone formation in vitro by stromal cells obtained from bone marrow of young adult rats. Cell and Tissue Research 254(2):317-330, 1988.

McCulloch CAG, Bordin S: Role of fibroblast subpopulations in periodontal physiology and pathology. Journal of Periodontal Research 26:144-154, 1991.

McCulloch CAG, Knowles G: Discrimination of two fibroblast progenitor populations in early explant cultures of hamster gingiva. Cell and Tissue Research 264:87-94, 1991.

McCulloch CAG, Melcher AH: Cell density and cell generation in the periodontal ligament of mice. The American Journal of Anatomy 167:43-58, 1983a.

McCulloch CAG, Melcher AH: Cell migration in the periodontal ligament of mice. Journal of Periodontal Research 18:339-352, 1983b.

McKee MD, Nanci A: Osteopontin at mineralized tissue interfaces in bone, teeth, and osseointegrated implants: ultrastructural distribution and implications for mineralized tissue formation, turnover, and repair. Microscopy Research and Technique 33(2)141-164, 1996.

Melcher AH: On the repair potential of periodontal tissues. Journal of Periodontology 47(5):256-260, 1976.

Melcher AH: Repair of Wounds in the periodontium of the rat. Influence of periodontal ligament on osteogenesis. Archives of Oral Biology 15:1183-1204, 1970.

Melcher AH, McCulloch CAG, Cheong T, Nemeth E, Shiga A: Cells from bone synthesize cementum-like and bone-like tissue in vitro and may migrate into periodontal ligament in vivo. Journal of Periodontal Research 22:246-247, 1987. 
Narayanan AS, Page RC: Connective tissues of the periodontium: a summary of current work. Collagen Related Research 3(1):33-64, 1983.

Ogiso B, Hughes FJ, Melcher AH, McCulloch CAG: Fibroblasts inhibit mineralised bone nodule formation by rat bone marrow stromal cells in vitro. Journal of Cellular Physiology 146:442-450, 1991.

Oh SP, Griffith CM, Hay ED, Olsen BR: Tissue-specific expression of type XII collagen during mouse embryonic development. Developmental Dynamics 196:37-46, 1993.

Oikarinen KS, Seppä ST: Effect of preservation media on proliferation and collagen biosythesis of periodontal ligament fibroblasts. Endodontics \& Dental Traumatology 3:9599, 1987.

Perera KAS, Tonge $\mathrm{CH}$ : Fibroblast cell population kinetics in the mouse molar periodontal ligament and tooth eruption. Journal of Anatomy 133(2):281-300, 1981.

Roberts WE, Chase DC: Kinetics of cell proliferation and migration associated with orthodontically-induced osteogenesis. Journal of Dental Research 60(2):174-181, 1981.

Söder PO, Otteskog P, Andreasen JO, Modéer T: Effect of drying on viability of periodontal membrane. Scandinavian Journal of Dental Research 85:164-168, 1977.

Ten Cate AR, Deporter DA: The role of the fibroblast in collagen turnover in the functioning periodontal ligament of the mouse. Archives of Oral Biology 19:339-340, 1974.

Wang HM, Nanda V, Rao LG, Melcher AH, Heersche JN, Sodek J: Specific immunohistochemical localization of type III collagen in porcine periodontal tissues using the peroxidase-antiperoxidase method. Journal of Histochemistry and Cytochemistry 28(11):1215-1223, 1980. 
Zohar R, Lee W, Arora P, Cheifetz S, McCulloch CAG, Sodek J: Single cell analysis of intracellular osteopontin in osteogenic cultures of fetal rat clavarial cells. Journal of Cellular Physiology 170:88-100, 1997. 